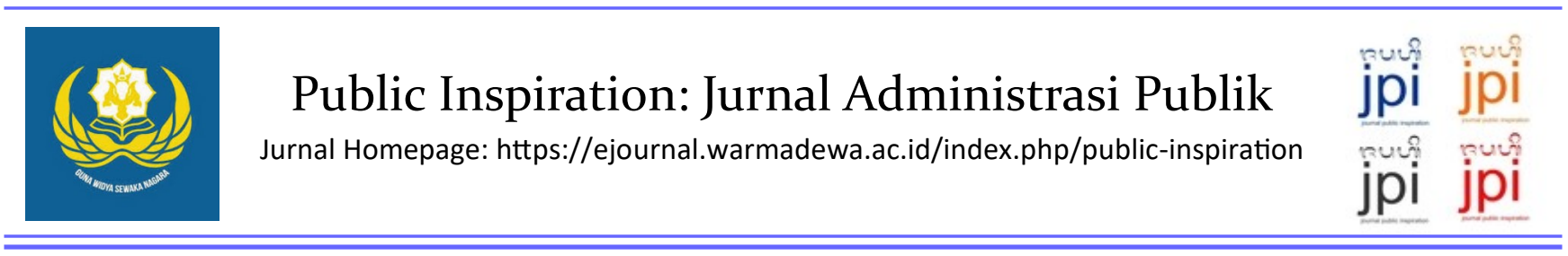

\title{
Perbandingan Manajemen Pegawai Negeri Sipil Indonesia dan Korea
}

\author{
Kim Dongil*, I Ketut Putra Erawan dan I Made Mardika \\ Magister Administrasi Publik, Universitas Warmadewa, Denpasar, Bali-Indonesia \\ Corespondence Email: kdi3337337@gmail.com
}

How to Cite: Dongil, K., Erawan, I. K. P., \& Mardika. I. M. (2021). Perbandingan Manajemen Pegawai Negeri Sipil Indonesia dan Korea. Public Inspiration: Jurnal Administrasi Publik, 6(1). 66-73. DOI: https://doi.org/10.22225/pi.6.1.2021.66-73

\section{Abstract}

This research focused on the study and comparison of PNS management system in Indonesia and Korea. This study aimed to understand the PNS management system in Indonesia and Korea through a comparison of PNS management systems in the two countries. As well as, the purpose of this study was to obtain implications that could contribute to the management of civil servants in Indonesia and to promote cooperation in the field of PNS management sistem between the two countries.

Keywords: Comparison; Management; Civil servants

\begin{abstract}
Abstrak
Penelitian ini difokuskan pada studi dan perbandingan sistem manajemen PNS di Indonesia dan Korea. Penelitian ini bertujuan untuk memahami sistem manajemen PNS di Indonesia dan Korea melalui perbandingan sistem manajemen PNS di kedua negara tersebut. Selain itu, tujuan dari penelitian ini adalah untuk memperoleh implikasi yang dapat memberikan kontribusi bagi pengelolaan pegawai negeri sipil di Indonesia dan untuk mendorong kerjasama di bidang sistem manajemen PNS antara kedua negara.
\end{abstract}

Kata kunci: Perbandingan; Manajemen; PNS

\section{Pendahuluan}

Di bidang administrasi publik, sistem manajemen PNS adalah bidang yang paling mendasar dan inti untuk mendukung seluruh administrasi publik. Oleh karena itu, bisa dikatakan bahwa keberhasilan sistem manajemen Pegawai Negeri Sipil (PNS) bisa mempengaruhi keberhasilan administrasi publik. Untuk mengembangkan sistem manajemen PNS, sistem yang disesuaikan dengan lingkungan administrasi setiap negara dibutuhkan. Namun, perbandingan, analisis dan pemahaman sistem negara lain sangat penting untuk mengatasi perubahan lingkungan administrasi yang cepat, kebutuhan administrasi yang beragam, dan perubahan administrasi global. Sebenarnya, negara negara di seluruh dunia terus menerus mengupayakan ketetapan sistem manajemen PNS yang paling optimal melalui penelitian perbandingan sistem dengan negara lain (Yunkwon, 2012).

Korea adalah satu - satunya negara di dunia yang sekarang menjadi negara pemberi sumbangan dari negara yang awalnya menjadi penerima sumbangan. Jadi, pengalaman sukses Korea telah menjadi model untuk pembangunan di banyak negara berkembang. Model pembangunan Korea berbeda dengan negara - negara maju dan harapan negara berkembang meningkat karena model ini bisa membantu secara nyata. Perkembangan Korea yang tinggi ini didukung oleh pelayanan administrasi publik yang cepat, efisien, dan profesional, serta dasar pelayanan administrasi publik ini adalah upaya pemerintah Korea untuk memberantas KKN dan membangun reformasi birokrasi. 
Upaya pemerintah Korea tersebut juga dimulai dari pengembangan sistem manajemen PNS,

Oleh karena itu, melalui perbandingan antara manajemen PNS di Indonesia dan Korea, Indonesia dapat mempelajari dan memahami sistem manajemen PNS Korea kemudian mendapat implikasi untuk mengembangkan sistem manajemen PNS Indonesia, Selain itu, Korea juga memahami sistem manajemen PNS Indonesia untuk kerja sama di bidang manajemen PNS antara kedua negara.

\section{Teori Perbandingan}

Perbandingan administrasi negara tersusun dari tiga konsep yang sangat bermakna, yaitu kata 'perbandingan', 'administrasi', dan kata 'negara (Kartiwa, 2012). Perbandingan, dapat diartikan pula dengan istilah menyamakan dan membedakan dua objek atau lebih objek tertentu, rnisalnya membandingkan objek kajian administrasi negara dengan administrasi negara lain. Administrasi dapat diartikan sebagai suatu proses pengorganisasian tugas - tugas dan kegiatan dari berbagai tingkatan dan jenis pekerjaan secara sistemik dalam organisasi. Selain itu administrasi negara adalah keseluruhan penyelenggaraan kekuasaan pemerintah dengan memanfaatkan dan mendayagunakan segala kemampuan aparatur negara serta segenap dana dan daya untuk terciptanya tujuan dan terlaksananya tugas negara. Dengan pengertian tersebut, dapat dipahami bahwa perbandingan administrasi negara adalah ilmu pengetahuan yang mengkaji sistem pelayanan negara dan penyelenggaraan negara dengan pendekatan perbandingan.

\section{Teori Manajemen Personalia}

Handouts Kursus Internasional Personel Management yang dikutip Mokhmad Syuhadhak manajemen kepegawaian adalah suatu tanggung jawab dari mereka yang mengelola pegawai, yang juga berarti merupakan suatu deskripsi pekerjaan dari mereka yang ditugasi sebagai spesialis spesialis kepegawaian (Syukhadak \& Mukhamad, 1996). Manajemen personalia adalah bagian dari manajemen yang berhubungan dengan pegawai di dalam bekerja dan dengan hubungannya di dalam perusahaan tersebut. Manajemen personalia tidak hanya berhubungan dengan sektor industri atau perdagangan, tetapi juga seluruh bidang ketenagakerjaan. Pendapat tersebut tidak memberikan porsi berbeda antara manajemen kepegawaian dengan manajemen personalia. Keduanya memiliki objek yang sama, yaitu berhubungan dengan pegawai, Personalia adalah kegiatan yang berkaitan dengan personalia, pegawai, atau tenaga kerja, sedangkan kepegawaian adalah ihkwal yang berkaitan dengan kedudukan, kewajiban, hak, dan pembinaan pegawai negeri. Dengan demikian maka istilah kepegawaian lebih lazim dipergunakan dalam kalangan pemerintah, sedangkan istilah personalia lebih dikenal dalam kalangan swasta (Rahman \& Bakri, 2019).

Handari Nawawi menghimpun berbagai pengertian manajemen Sumber Daya Manusia (SDM) yang kemungkinan besar hasil analysis dari banyak sumber, yaitu:

(1) Manajemen SDM adalah proses pendayagunaan bantuan orang lain secara manusiawi, agar memberikan kontribusi terbaik dalam pencapaian tujuan organisasi (publik).

(2) Manajemen SDM adalah kemampuan mendayagunakan dan memperlakukan orang lain secara manusiawi, agar terintegrasi dengan sumber daya lainnya, dalam mewujudkan organisasi nonprofit yang sehat/baik dan mampu mengembangkan eksistensinya sesuai kondisi lingkungan yang terus berubah,

(3) Manajemen SDM adalah usaha mewujudkan organisasi publik yang eksistensinya dibutuhkan oleh masyarakat, melalui perencanaan dan tindakan pemberian pelayanan umum (public service) dan pelaksanaan pembangunan untuk kesejahteraan masyarakat, yang berfokus pada peningkatan kemampuan kerja pelaksanaannya secara berkelanjutan berdasarkan etika dan tanggung jawab sosial yang tinggi dalam bekerja (Nawawi \& Handari, 2003). 
Selanjutnya Amstrong membahas pengertian manajemen kepegawaian meliputi: (1) Memperoleh, mengembangkan dan memotivasi SDM yang dibutuhkan oleh organisasi untuk mencapai tujuannya (2) mengembangkan struktur dan suasana organisasi dan mengembangkan gaya manajemen yang akan mempromosikan kerja sama dan komitmen di seluruh organisasi (3) memanfaatkan keterampilan dan kapasitas semua pegawai yang dipekerjakan dalam organisasi dengan sebaik - baiknya, (4) memastikan bahwa organisasi memenuhi tanggung jawab sosial dan hukumnya terhadap pegawainya, dengan memperhatikan kondisi kerja dan kualitas kehidupan kerja yang disediakan bagi pegawai (Syukhadak \& Mukhamad, 1996).

Berdasarkan penjelasan dari para ahli di atas, dapat ditarik simpulan bahwa manajemen PNS adalah serangkaian proses seperti kegiatan perencanaan dan pengelolaan untuk memperoleh, mengembangkan, dan memanfaatkan SDM yang dibutuhkan untuk mencapai tujuan organisasi. Selain itu, manajemen PNS berarti strategi manajemen untuk meningkatkan efisiensi administrasi publik dengan merekrut dan mengelola (meningkatkan semangat dan mengembangkan keterampilan) SDM yang dibutuhkan untuk mencapai tujuan pemerintah.

\section{Hasil dan Pembahasan}

Untuk membandingkan bidang manajemen PNS antara Indonesia dan Korea, jurnal ini ditulis melalui perbandingan masing - masing bidang yang terdiri atas unsur - unsur manajemen PNS.
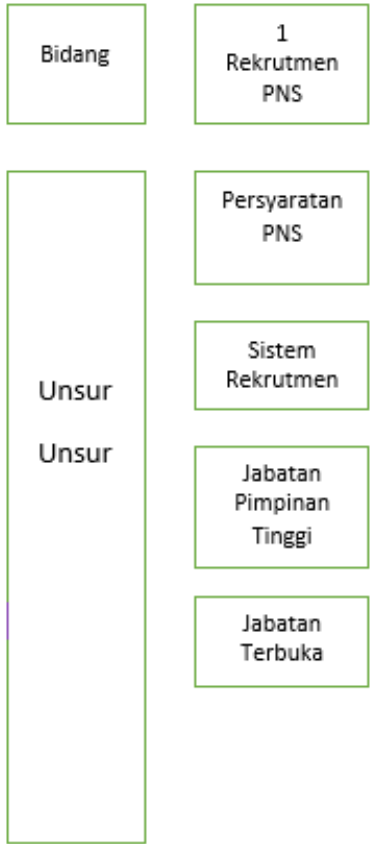

Persyaratan

PNS
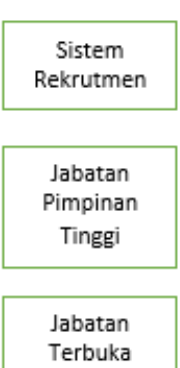

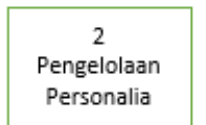

Personalia
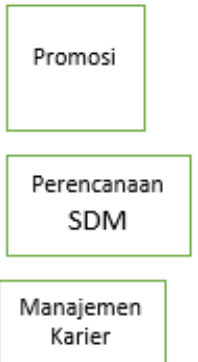

Penilaian

Kinerja

Pendidikan Dan

Pelatihan
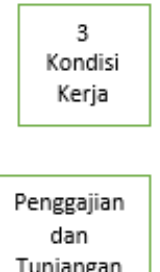

Tunjangan

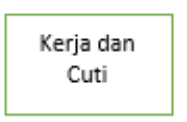

Kewajiban Dan Disiplin
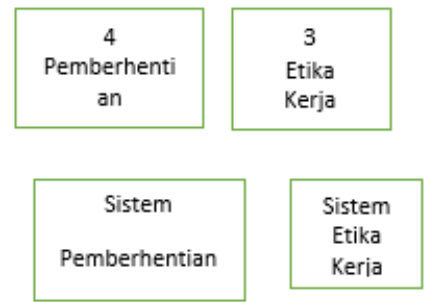

Uang Pensiun

\section{Gambar 1}

Unsur Unsur Manajemen PNS

\section{Rekrutmen PNS}

(1) Persyaratan untuk menjadi PNS, Indonesia menentukan persyaratan untuk bisa menjadi PNS. Sementara Korea menentukan persyaratan untuk tidak bisa menjadi PNS. Mengingat bahwa peraturan secara negatif lebih terbuka daripada peraturan secara positif, peraturan secara negatif dapat membuka jalan yang lebih luas bagi masyarakat untuk menjadi PNS, Selain itu, batas usia untuk melamar menjadi PNS Indonesia adalah 18 sampai dengan 35 tahun. Namun, pemerintah Korea telah menghapuskan batas usia paling tinggi sejak tahun 2009. Jadi, Warga negara Korea dapat melamar 
Public Inspiration: Jurnal Administrasi Publik, 6 (1) (2021), 69

Perbandingan Manajemen Pegawai Negeri Sipil Indonesia dan Korea

menjadi PNS hingga usia 60 tahun, Penghapusan batas usia pendaftaran CPNS di Korea dilakukan untuk mendapat SDM berkualitas tinggi dan kompeten.

(2) Dalam sistem rekrutmen, Indonesia telah memprioritaskan proses untuk mencegah KKN dan memberikan keadilan dalam ujian CPNS. Untuk itu, Salah satu upaya yang dilakukan adalah implementasi sistem Computer Assisted Test (CAT). CAT dapat mewujudkan efisiensi, efektivitas, transparansi dan akuntabilitas penyelenggaraan pemerintahan, khususnya dalam melaksanakan proses rekrutmen CPNS (Yasin, 2015). CAT adalah sistem yang lebih maju daripada sistem rekrutmen CPNS di Korea karena pelamar langsung mengerjakan soal ujiannya di layar monitor komputer. Sistem tes ujian CPNS di korea masih menggunakan lembar jawaban OMR (Optical Mark Reader).

Mengenai proses rekrutmen persaingan umum, Indonesia melaksanakan seleksi administrasi dulu, kemudian melaksanakan seleksi tertulis, yaitu seleksi kompetensi dasar dan seleksi kompetensi bidang. Sementara Korea melaksanakan seleksi administrasi setelah pengumuman kelulusan ujian tertulis, Untuk mencegah kolusi dan nepotisme pemerintah Korea menerima dan memeriksa surat atau dokumen yang dibutuhkan terkait dengan persyaratan PNS setelah pengumuman kelulusan ujian tertulis,

(3) Mengenai Jabatan Pimpinan Tinggi (JPT) Indoneisa, Korea juga menjalankan Pejabat Pimpinan Tinggi (PPT). Sistem ini di kedua negara dilaksanakan untuk meningkatkan kualitas pejabat tinggi dan memotivasi pencapaian pekerjaannya dengan membedakan tingkat menengah dan bawah, Oleh karena itu, isi pokok sistem JPT di Indonesia dan PPT di Korea hampir sama. Namun, ketika PNS dipromosikan menjadi PPT di Korea, pemeriksaan tugas yang ketat dilaksanakan. Selain itu PPT di Korea dievaluasi selama bekerja dan jika PPT dinilai buruk, PPT bisa diberhentikan paksa atau diberikan kesempatan pendidikan dan pelatihan untuk memperbaiki kemampuannya. Sementara Indonesia tidak mempunyai proses terhadap JPT seperti sistem PPT Korea.

(4) Jabatan yang diisi terbuka tidak jelas ditentukan di peraturan Indonesia, tetapi pemerintah Indonesia sudah mengelola sistem mi di sisi pengisian JPT. Sementara itu, peraturan Korea menentukan bahwa setiap menteri harus menetapkan rasio jumlah jabatan tertentu yang di isi secara terbuka, Selain itu, Korea mengelola jabatan yang di isi secara terbuka tidak hanya untuk jabatan PPT tetapi juga untuk kepala departemen (bukan PPT), Sementara Indonesia mengelola jabatan yang di isi terbuka terhadap cuma jabatan PPT,

\section{Pengeloahan Personalia}

(1) Mengenai promosi, Indonesia dan Korea memiliki kesamaan dalam promosi dilaksanakan sesuai dengan kemampuan, kinerja dan senioritas. Namun, Korea menjalankan dua cara untuk promosi, yaitu sistem ujian dan sistem penilaian untuk kenaikan pangkat Sementara Indonesia menjalankan satu cara untuk promosi, yaitu sistem penilaian untuk kenaikan pangkat, Sistem ujian untuk kenaikan pangkat di Korea bertujuan mencegah KKN dan memberikan peluang promosi untuk PNS tingkat 6 yang bekerja di departemen yang tidak bisa menerima penilaian yang baik seperti departemen pelaksanaan atau departemen yang terletak di daerah. Selain itu, di Indonesia jenjang pendidikan adalah salah satu syarat penting dalam kenaikan pangkat. Sementara, di Korea jenjang pendidikan tidak dibutuhkan karena pemerintah Korea menganggap syarat jenjang pendidikan untuk kenaikan pangkat tidak sesuai dengan sistem merit.

(2) Indonesia dan Korea menyusunkan pengelolaan perencanaan SDM untuk memprediksi penawaran dan permintaan tenaga kerja yang dibutuhkan untuk mencapai tujuan pemerintah dan mencari penyediaan kerja yang paling optimal berdasarkan prediksi penawaran dan permintaan tenaga kerja tersebut. Perencanaan pengelolaan SDM Korea berbeda dari perencanaan pengelolaan SDM Indonesia karena Korea mencakup tidak hanya penawaran serta permintaan tenaga kerja, tetapi juga pendidikan, pelatihan, manajemen kinerja, manajeman karier dan strategi pemilihan orang berkompetensi. Sementara pengelolaan perencanaan SDM Indonesia mencakup hanya penawaran 
serta permintaan tenaga kerja.

(3) Mengenai manajemen karier, baik Indonesia maupun Korea mempunyai kesamaan dalam mengembangkan kompetensi individu PNS untuk mencapai tujuan organisasi dan melakukan manajemen karier melalui upaya untuk menyesuaikan tujuan pengembangan karier induvidu PNS dengan tujuan organisasi. Namun, Indonesia biasanya menggunakan promosi dan mutasi sebagai metode manajemen karier, sementara Korea selain promosi dan mutasi menggunakan berbagai metode seperti sistem kerja jangka panjang, sistem pengiriman, pertukaran personalia, dan lain-lain. Korea menggunakan berbagai metode ini karena pembinaan administrator yang berkompetensi di bidang umum melalui promosi dan mutasi dibutuhkan, tetapi pembinaan ahli yang memiliki keahlian di bidang tertentu membutuhkan berbagai sistem manajemen karier untuk merespons berbagai permintaan administrasi serta perubahan lingkungan dan meningkatkan kualitas layanan publik,

(4) Mengenai penilaian kinerja, Indonesia dan Korea mempunyai kesamaan di sisi konsep dan tujuan penilaian kinerja. Selain itu, proses penilaian kinerja PNS hampir sama antar kedua negara. Namun, di Korea pengajuan pendapat lain dari objek penilaian termasuk ke dalam proses penilaian kinerja pada sistem Korea. Sementara di Indonesia pengajuan pendapat lain tidak ada dalam proses penilaian kinerja. Penilaian kinerja sangat penting karena hasil penilaian mempengaruhi gaji, tunjangan, promosi, dan mutasi seorang PNS. Oleh karena itu, pemerintah Korea menjalankan pengajuan pendapat lain,

(5) Mengenai pendidikan dan pelatihan PNS, Indonesia dan Korea memiliki kesamaan dalam konsep dan tujuan seperti dicantumkan di perundang-undangan. Khususnya pendidikan dasar dijalankan di Korea hampir mirip dengan Diklat di Indonesia. Namun ada perbedaan antara kedua negara, yaitu pendidikan PNS Korea dilaksanakan secara mandiri oleh individu PNS dan waktu pendidikan tersebut digunakan untuk kenaikan pangkat PNS Korea, Ketika PNS naik pangkat, PNS tersebut membutuhkan waktu pendidikan tertentu (sekitar 80 jam per tahun) yang ditetapkan oleh masing-masing kementerian, Tentu saja, di Indonesia gelar akademik dibutuhkan untuk kenaikan pangkat, dan PNS harus menyelesaikan waktu pendidikan tertentu untuk mendapatkan gelar akademik. Akan tetapi, di Korea, otonomi untuk memilih metode pendidikan diberikan kepada PNS untuk mendukung pengembangan diri PNS.

\section{Kondisi Kerja}

(1) Indonesia menjalankan satu sistem penggajian PNS, yaitu sistem gaji tingkatan. Sementara Korea menjalankan dua sistem penggajian PNS, yaitu sistem gaji tingkatan dan sistem gaji tahunan, Di Korea, gaji tingkatan diterapkan ke PNS tingkat 6 -- 9 dan gaji tahunan diterapkan kepada ASN politik, PPT, PNS tingkat 5 -- 1. Sistem gaji tahunan lebih menekankan hasil kinerja daripada sistem gaji tingkatan. Selain itu, mengenai sistem gaji tingkatan, pada dasarnya, tidak ada perbedaan yang terlalu signifikan antara kedua negara. Sistem gaji tingkatan ditentukan oleh tabel gaji pokok menurut pangkat dengan ditambah beberapa tunjangan. Namun ada perbedaan yang cukup signifikan di tunjangan kinerja antara kedua negara. Kesenjangan jumlah tunjangan kinerja di Indonesia sangat tinggi antar instansi, Menurut instansi - instansi kesenjangan jumlah kinerja adalah 0,7 juta - 10 jutaan per bulan. Di Korea, jumlah tunjangan kinerja tidak berbeda menurut masing-masing instansi. Total jumlah tunjangan kinerja ditentukan oleh jumlah pegawai menurut instansi, kemudian diberikan secara berbeda ke PNS di dalam instansi. Alasan untuk tidak membuat perbedaan dalam pernbagian tunjangan kinerja adalah pentingnya pekerjaan yang dilakukan oleh masing - masing instansi tidak bisa diukur. Selain itu, cara pembagian jumlah tunjangan PNS antara kedua negara berbeda, Indonesia membagikan tunjangan kinerja pada setiap bulan berdasarkan jabatan, sementara Korea membagikan rasio tertentu dari gaji pokok setiap setahun sekali. Di Korea, pembagian tunjangan kinerja dibagikan dari $0 \%$ sampai $172,5 \%$ di dalam tingkatan yang sama melalui penilaian kinerja. Ini adalah kebijakan pembagian tunjangan kinerja berdasarkan kinerja individu di dalam tingkat dan bidang yang sama melalui penilaian kinerja yang tepat setiap tahun. 
(2) Mengenai jam kerja, jam kerja PNS Indonesia adalah 37,5 jam sementara jam kerja PNS Korea adalah 40 jam seminggu. Waktu makan siang sama di kedua negara, yaitu jam 12:00 -- 13:00. Namun di Indonesia sebagian besar PNS tidak bekerja selama waktu makan siang, sementara di Korea, departement yang secara langsung melayani masyarakat secara bergantian menggunakan waktu makan siang untuk kenyamanan masyarakat. Selanjutnya, mengenai cuti, tidak ada perbedaan besar yang terlalu signifikan antara sistem Indonesia dan Korea. Peraturan di kedua negara menjamin cuti tahunan, cuti sakit, cuti khusus, cuti kelahiran, dan lain - lain, Namun, peraturan di Indonesia menetapkan secara resmi untuk dapat menolak pengajuan cuti tahunan dan cuti besar. Di Korea, tidak ada peratuaran seperti di atas. Sebaliknya, kepala instansi harus mengumumkan jumlah hari wajib untuk PNS affliasi menggunakan cuti tahunan dan PNS harus menggunakan jumlah hari cuti tahunan yang diwajibkan.

(3) Tidak ada perbedaan signifikan yang ditemukan antara Indonesia dan Korea mengenai kewajiban dan hukuman disilpin PNS. Namun, dalam hal hukuman disiplin, hukuman disiplin diselesaikan secara sendiri di Indonesia, tetapi di Korea, selain hukuman disiplin sendiri, ada efek tambahan seperti pembatasan kenaikan pangkat dan pengurangan gaji. Efek tambahan hukuman disiplin dimaksudkan untuk membuat efek hukuman disiplin lebih kuat sehingga mencegah PNS melanggar kewajiban dan disiplin.

\section{Pemberhentian}

(1) Mengenai sistem pemberhentian PNS, alasan pemberhentian PNS hampir mirip di sistem kedua negara. Perbedaannya hanya dalam sistem Korea, pemerintah Korea menjalankan sistem pemberhentian dengan kehonnatan. Sistem pemberhentian dengan kehormatan merupakan pemberian uang tambahan kepada PNS yang secara sukarela mengakhiri kedudukannya sebelum PNS tersebut mencapai usia pensiun. Sistem ini dijalankan untuk mencegah penghentian dan kemacetan efisiensi administrasi melalui pemberhentian awal, Selain itu, tujuan sistem ini adalah memberikan kesempatan maju ke bidang swasta kepada PNS untuk menyesuaikan diri pada bidang swasta. Sistem ini juga efektif dalam mengurangi anggaran pemerintah dengan merekrut PNS yang baru sebagai ganti PNS yang lama. Sementara itu, di Indonesia tidak terdapat sistem tersebut,

(2) Mengenai uang pensiun, Indonesia menjalankan satu metode pembayaran uang pensiun. Sementara Korea menjalankan dua metode pembayaran uang pensiun yaitu, uang pensiun dan uang pensiun sekaligus. Biasanya uang pension dibagikan pada setiap bulan, tetapi uang pensiun sekaligus dibagikan pada satu kali dengan jumlahnya cukup besar. Oleh karena itu, PNS Korea bisa memilih cara pembayaran uang pensiun apakah dibayar sekali, sebagian atau setiap bulan. Selain itu, Indonesia menghitung uang pensiun hanya dengan mempertimbangkan pangkat terakhir. Sementara Korea menggunakan metode perhitungan uang pensiun seperti mempertimbangkan tingkat akhir dan jangka waktu kerja. Selain itu, jika PNS Korea diberhentikan dengan tidak hormat oleh hukum disiplin atau / dan hukum pidana, uang pensiun dipotong sampai setengah. Sementara Indonesia tidak mempunyai sistem potong uang pensiun.

\section{Etika PNS}

(1) Untuk mengatasi KKN, selain pascakontrol seperti hukuman, prakontrol sangat penting. Sebagai prakontrol sistem etika, pemerintah Korea dan Indonesia juga menjalankan sistem pelaporan harta kekayaan terhadap PNS untuk mencegah KKN, tetapi ada kekurangan di sistem Indonesia dibandingkan dengan sistem etika Korea. Dalam Laporan Harta Kekayaan Aparatur Sipil Negara (LHKASN) di Indonesia, ada beberapa kekurangan dalam efektivitas di sistem, seperti tidak diwajibkannya pelampiran bukti daftar harta kekayaan oleh PNS serta tidak ada sanksi bagi PNS yang melanggar kewajiban tersebut. Sementara itu, di Korea PNS wajib melampirkan bukti daftar harta kekayaan serta ada sanksi bagi PNS yang melanggar kewajiban tersebut. Selain pelaporan harta kekayaan, Korea menjalankan beberapa sistem etika PNS seperti penjualan serta penitipan saham, 
Public Inspiration: Jurnal Administrasi Publik, 6 (1) (2021), 72

Perbandingan Manajemen Pegawai Negeri Sipil Indonesia dan Korea

pelaporan hadiah, larangan permintaan serta bantuan pendapatan pekerjaan, penentuan organisasi terkait dengan pekerjaan PNS, dan sistem etika pekerjaan PNS pemberhentian sebagai sistem prakontrol.

\section{Simpulan}

Sebagai hasil dari perbandingan sistem manajemen PNS di Indonesia dan Korea, dapat disimpulkan bahwa sistem Indonesia di setiap bidang manajemen PNS kurang memiliki demokrasi, keanekaragaman dan efektivitas daripada sistem manajemen PNS Korea. Contohnya, di sisi demokrasi, Indonesia masih mengatur batasan usia dan jenjang pendidikan sebagai persyaratan untuk melamar CPNS, Selain itu, dalarm proses penilaian kinerja tidak ada peraturan untuk pengaduan pendapat lain oleh objek PNS, Di sisi keanekaragaman, Korea menjalankan dua sistem penggajian, dua sistem pembayaran uang pensiun, dari berbagai sistem etika PNS, sedangkan Indonesia menjalankan satu sistem di bidang - bidang tersebut, Di sisi efektivitas, Indonesia kurang memiliki sistem untuk menjamin efektivitas seperti evaluasi selama bekerja terhadap JPT, pembatasan gaji, uang pensiun serta kenaikan pangkat terhadap PNS yang dihukum disiplin, dan sanksi terhadap PNS yang melanggar kewajiban pelaporan kekayaan di Korea.

Pengaturan Manajemen PNS dalam praktiknya ditentukan oleh norma - norma yang mendasari peraturan/hukurn suatu negara. Kasus Korea menekankan kepastian hukum, akuntabilitas dan efisiensi, sedangkan kasus Indonesia menunjukan kelemahan dimensi-dimensi tersebut. Tekanan Indonesia pada etika yang tidak berimplikasi ke kepastian hukum dapat dijelaskan oleh masuknya pertimbangan - pertimbangan politis pada ranah administrasi,

\section{Daftar Pustaka}

Kartiwa, H, A. 2012. Perbandingan Administrasi Negara. Bandung: Pustaka Setia.

Kementerian Manajemen ASN. 2017.

Keputusan Presiden Republik Indonesia Nomor 68 Tahun 1995 tentang Han Kerja di Lingkungan Lembaga Pemerintah

Keputusan Kepala BKN No. 13 Tahun 2002 tentang Keputusan Pelaksanaan Peraturan Pegawai Negeri Sipil dalam Jabatan Struktural sebagaimana telah Diubah dengan Peraturan Pemerintah No. 13 Tahun 2002

Nawawi, H. 2003. Manajemen Strategik Organisasi Non Profit Bidang Pemerintahan Dengan Ilustrasi Di Bidang Pendidikan. Yogyakarta: Gajah Mada University Press

Pedoman Manajemen PNS Sejong: Kementerian Manajemen ASN.

Peraturan Pemerintah Republik Indonesia Nomor 11 Tahun 2017 tentang Manajemen Pegawai Negeri Sipil

Peraturan Presiden tentang Ujian Pengangkatan PNS

Peraturan Presiden Undang-Undang tentang Pengembangan Kompetensi PNS

Peraturan Pemerintah Manajemen PNS

Peraturan Pemerintah tentang Jabatan Secara Umum dan Terbuka

Peraturan Pemerintah tentang Penilaian Kinerja PNS

Peraturan Pemerintah tentang Tunjangan Pegawai Negeri Sipil

Peraturan Pemerintah tentang Penugasan Pegawai Negeri Sipil Negara

Rahman, A., \& Bakri, R. 2019. Penataan pengeloaan Aparatur Negara Sipil Negara (ASN) melalui dynamic governance. Jurnal Konstituen, Vol 1, Nomor 1.

Simanungkalit, J, H, U, P. 2007. Perkembangan sistem kepegawaian negara: Perspektif Komparatif Arnerika 
Public Inspiration: Jurnal Administrasi Publik, 6 (1) (2021), 73

Perbandingan Manajemen Pegawai Negeri Sipil Indonesia dan Korea

Serikat dan Indonesia. Pusat pengkajian dan penelitian kepegawaian BKN, Vol 1, Nomor 2.

Surat Edaran Menteri Pendayagunaan Aparatur Negara dan Reformasi Birokrasi Nomor 1 Tahun 2015 tentang Kewajiban Penyampaian Laporan Harta Kekayaan Aparatur Sipil Negara

Syukhadak, M. 1996. Administrasi Kepegawaian Negara Teori dan Praktik Penyelenggaraannya di Indonesia. Jakarta: PT. Toko Gunung Agung.

Undang-undang Nomor 28 Tahun 1999 tentang Penyelenggaraan Negara yang Bersih dan Bebas dari Korupsi, Kolusi, dan Nepotisme

Undang - undang Republik Indonesia Nomor 5 Tahun 2014 tentang Aparatur Sipil Negara Undang-undang Republik Indonesia Nomor 11 Tahun 1969 tentang Pensiun Pegawai dan Pensiun Janda/Duda Pegawai

Undang-undang Republik Indonesia Nomor 11 Tahun 1992 tentang Dana Pensiun

Undang-undang tentang Aparatur Sipil Negara

Undang-undang tentang Uang Pensiun Pegawai Negeri Sipil

Undang-undang tentang Etika Aparatur Sipil Negara

Yasin, R. 2015. Implementasi Kebijakan Pemerintah Dalam. Rekrutmen Dengan Sistem Computer Assisted Test. Jurnal Ilmu Administrasi Negara, Volume 13, Nomor 2

Yunkwon, K. 2012. Penelitian Perbandingan Sistem Promosi dan Rekrutmen PNS antara Korea, Cina, dan Jepang. The Korea Institute of public A dministration. 